Original Paper http://ajol.info/index.php/ijbcs http://indexmedicus.afro.who.int

\title{
Germination responses of Cola acuminata (Pal. De Beauv.) seeds to different substrates, photoperiods and dehydration
}

\author{
Gabriel KANMEGNE*, Gaby FAMEN KAMTAT and Théophile FONKOU
}

Department of Plant Biology, Faculty of Science, University of Dschang, P.O. Box 67 Dschang, Cameroon. *Corresponding author, E-mail: gkanmegne@yahoo.com; Telephone (+237) 677490069

\begin{tabular}{lll}
\hline Received: $30-12-2020$ & Accepted: 14-04-2021 & Published: 30-04-2021 \\
\hline
\end{tabular}

\begin{abstract}
Cola acuminata (Pal. De Beauv.), one of the many forest tree species which are of socio-economic importance in Western and Central Africa, is still exploited in the wild by subsistence farmers because it has not been domesticated yet. As a contribution to its domestication, the present study aimed at determining germination requirements and desiccation tolerance of seeds. Three substrates (forest topsoil, river sand and mixture of forest top soil and river sand), two photoperiods (12 hours/day and continuous darkness) and dehydration were investigated for their effects on seeds germination percentage. To evaluate the seeds' tolerance to desiccation, fresh seeds were dried at laboratory temperature for 16 days during which seeds moisture content, seeds germination percentage and electrical conductivity of seeds leachate were monitored at two-day intervals. Results showed that the mean germination percentage recorded on the mixture of forest top soil and river sand (97.2 \pm $1.0 \%$ ) was significantly higher than that recorded on forest topsoil $(85.5 \pm 4.0 \%)$, which was in turn higher than that obtained on river sand $(70 \pm 1.5 \%)$. The effect of photoperiod on germination percentage was not significant $(\mathrm{p}=0.112)$. As response to seeds drying, the mean germination percentage slightly decreased as moisture got lost, then drastically dropped when moisture content was below $45.95 \pm 4.2 \%$. Seeds failed to germinate when their moisture content fell below $27.1 \pm 2.1 \%$. Electrical conductivity of seed leachate exhibited a highly significant negative correlation with both germination percentage $(p<0.01, r=-0.926)$ and moisture content $(p$ $<0.01, \mathrm{r}=-0.931$ ). It is concluded that the best substrate for $C$. acuminata seeds' germination is the mixture of forest top soil and river sand in a 1/1 (v/v) ratio. Cola acuminata seeds are desiccation-sensitive and their storage behavior is recalcitrant. This is a significant constraint for conservation that should be addressed in further researches.
\end{abstract}

(C) 2021 International Formulae Group. All rights reserved.

Keywords: Cola acuminate, seed germination, photoperiod, desiccation tolerance, moisture content, storage behavior.

\section{INTRODUCTION}

Non timber forest products (NTFPs) are biological products from forest other than timber. In the humid tropics of West and Central Africa, NTFPs from plant origin are of direct relevance to the well-being of the people as they are used as human food, forage for domestic animals, medicine, fuel-wood, raw material for industries and craftsmen, and in cultural ceremonies. Commercialization of NTFPs in both domestic and national markets provides substantial income which raises the 
standard of living of those involved in their trading activity (Lim, 2012; Kokoutse et al., 2014). Many of the tree species producing NTFPs have multiple uses, and wherever grown, they are highly valued by local farmers (Atangana et al., 2014). Despite their socioeconomic importance, most of the tree species producing NTFPs remain essentially wild, and very little scientific knowledge is available on their growth, management and propagation (Sinclair and Joshi, 2001). Thus, there is a huge opportunity for increasing incomes through their domestication in cultivated setting. Indeed, the domestication of indigenous trees producing high-value products is a strategic component for the intensification and diversification of smallholder farming systems in the tropic and subtropics (Leakey and Tchoundjeu, 2001).

Cola acuminata (Pal. De Beauv.) Malvaceae (APG III, 2009) is one of the many forest tree species which are of socio-economic importance for millions of people in Western and Central Africa (Gebissa, 2006). It is a tree growing in humid lowlands of Sub-Saharan tropical forests where it is exploited by subsistence farmers as shade over cacao and/or coffee plants and for its edible seeds which are commonly called cola nuts (Duke, 2001). The economic and social importance of cola nuts cannot be emphasized enough. Indeed, it is one of the highest valued non timber forest products of West and Central Africa where it is extensively used as stimulant, social lubricant, ingredient in the manufacture of pharmaceuticals and traditional soft drinks. Cola nut used to be an ingredient in coca cola (Benjamin et al., 1999). Cola nut has a strong cultural significance in West and Central Africa, where without it, traditional hospitality, cultural and social ceremonies are considered incomplete. Cola nuts have for hundreds of years been widely traded in Africa, especially in the trans-Saharan trade routes (Gebissa, 2006; Asogwa et al., 2012a), The commercialization of cola nut in both the domestic and national markets raises the standard of living of those involved in its trade (Gebissa, 2006; Asogwa et al., 2012b).
Given the socio-economic importance of $C$. acuminata and the possibility of growing it in agroforestry systems, the species has been identified through a priority setting exercise as one of the priority targets for domestication in West and Central Africa (Atangana et al., 2014). As a step in the process of domestication of this species, researches on seed germination physiology are needed. Previous researches on germination of Cola sp seeds were focused on $C$. anomala and $C$. nitida rather than $C$. acuminata (Kanmegne et al., 2015). Indeed, $C$. acuminata is known to propagate naturally by seeds (Fotso et al., 2002), but the characteristics of seed germination have not been documented to date. Moreover, classification of seed storage behavior has not been made for this species.

The present study represents a step in the process of $C$. acuminata domestication. The general objective was to determine the requirements for seed germination.

\section{MATERIALS AND METHODS Seed material}

C. acuminata seeds were collected in two localities both belonging to the humid forest with bimodal rainfall agro ecological zone of Cameroon: Bafia $\left(4^{\circ} 45^{\prime} \mathrm{N}, 11^{\circ} 14^{\prime} \mathrm{E}\right.$, altitude $467 \mathrm{~m})$ and Ebebda $\left(4^{\circ} 20^{\prime} \mathrm{N}, 11^{\circ} 16^{\prime} \mathrm{E}\right.$, altitude $308 \mathrm{~m})$. In each locality, mature and disease-free pods were harvested from a minimum of twelve randomly selected trees in May 2017. A minimum of 100 pods (containing 1 to 10 seeds each) were harvested from each site and immediately brought to the Laboratory of Applied Botany of the University of Dschang. In the laboratory, seeds were extracted from pods 24 hours after harvest and processed by removing their white and soft testa, to obtain red coloured fresh nuts, which were mixed in a single batch and used for further experiments.

\section{Germination assay}

Seeds from the single batch were sown in black plastic perforated polythene bags (20 $\mathrm{cm}$ height and $10 \mathrm{~cm}$ diameter) filled with substrate which was either forest top soil, river sand or a mixture of forest top soil and river 
sand in 1:1 (v:v) ratio. As light regime (photoperiod) was one of the topics of investigation, sowing was done such that $3 / 4$ of the volume of seed was buried in the substrate while the remaining $1 / 4$ was visible above. The seeded polythene bags were then placed in the nursery $\left(22 \pm 3{ }^{\circ} \mathrm{C}\right)$ at two different photoperiods: natural photoperiod (12 hours/day) and continuous darkness. Darkness was provided by placing the seeded polythene bags in wooden boxes ( $1 \mathrm{~m} \times 1 \mathrm{~m} \times 0.5 \mathrm{~m})$ whose internal walls were lined with black and thick polythene paper.

In order to investigate on $C$. acuminata seed germination, two photoperiods (12 hours/day and continuous darkness) and three substrates [forest top soil, river sand and 1:1 (v:v) mixture of forest top soil and river sand] were tested in a $2 \times 3$ factorial experiment. Under each photoperiod, four replications each of 50 seeds were used for each substrate, making a total of 1200 seeds for the assay (2 photoperiods $\mathrm{x} 3$ substrates $\mathrm{x} 4$ replications $\mathrm{x}$ 50 seeds). Water was applied daily to the seeded polythene bags using a sprayer. Nuts with radicle protrusions and/or with the emergence of the plumule were recorded as having germinated. Germination was recorded daily, and the experiment was finished after 45 days, when no further germination was observed over a period of 10 consecutive days.

\section{Desiccation tolerance test}

Mature seeds harvested from a single tree in Bafia were used for the desiccation tolerance test. Fresh seeds were extracted from mature pods 24 hours after harvest and processed as described above. They were then spread in a single layer on the laboratory bench top and left to dry under shade at laboratory temperature $\left(24 \pm 1{ }^{\circ} \mathrm{C}\right)$. Laboratory relative humidity was $55 \pm 5 \%$. Seed samples were withdrawn at 2-day intervals for the measurement of moisture content and electrical conductivity of seed leachate, and for the germination test. Moisture content was determined by the oven dry method which consisted in weighing seeds before and after oven dried at $103{ }^{\circ} \mathrm{C}$ for $24 \mathrm{~h}$. Moisture content, which was expressed as a percentage of fresh weight, was calculated using the following formula: $M C(\%)=[(F W-D W) \div F W] \times$ 100

Where FW (fresh weight) is weight of sample before drying and DW (dry weight) is weight of sample after drying (ISTA, 2004). The value of the moisture content for each drying time was the mean of six measurements (six replications of one seed each).

For the measurement of electrical conductivity of seed leachate, a square of seed piece (cotyledon) was cut, weighed and soaked in distilled water in a $100 \mathrm{ml}$ beaker ( $3 \mathrm{~g}$ of seed piece in $50 \mathrm{ml}$ of distilled water). The beaker was covered and left in the laboratory at $24 \pm 1$ ${ }^{\circ} \mathrm{C}$ for $24 \mathrm{~h}$. Two beakers with $50 \mathrm{ml}$ of distilled water, but no seed piece, were treated similarly as blanks to determine the base conductivity of the water. After $24 \mathrm{~h}$, the seed piece was strained from the water and, the conductivity of the water was measured using a HACH Model of Conductivity/TDS Meter. The mean conductivity of the blanks was subtracted from each sample reading. Conductivities were expressed in microSiemens $(\mu \mathrm{S})$. Six replications were carried out at each drying time.

At 2-day intervals, four replications of 50 seeds each were withdrawn for the germination test which was carried out in the nursery at $22 \pm 3{ }^{\circ} \mathrm{C}$, natural photoperiod (12 hours of light per day) and in black polythene bags filled with a mixture of forest top soil and river sand as substrate. The seeded polythene bags were then regularly watered and germination percentages were recorded after 45 days as described above.

\section{Statistical analysis}

Data analyses were performed using SPSS 16.0 software package. The dependent variable was the mean germination percentage, whose data were transformed into arcsine square root values before statistical analysis. Analyses of variance (ANOVA) were performed to determine the level of significance of the main effects of germination substrate and photoperiod, as well as the 
significance of the effect of treatment combinations (Substrate $\mathrm{x}$ Photoperiod). Means that exhibited significant differences $(\mathrm{P}<0.05)$ were separated using Duncan's multiple comparison test or t-test as appropriate.

The 2-tailed Pearson's correlation coefficient was used to establish correlations between the different seed variables investigated (moisture content, germination percentage, and electrical conductivity of seed leachate). The critical water content of seeds was recorded at the point where the germination percentage significantly decreased while the lethal water content was recorded at the point where there was total failure of germination.

\section{RESULTS}

\section{Effect of substrate and photoperiod on germination percentage}

Results of the analysis of variance (Table 1) showed that substrate as well as treatment combination (substrate $\mathrm{x}$ photoperiod) had a highly significant effect ( $\mathrm{p}$ $\leq 0.001$ ) on germination percentage of $C$. acuminata seeds, whereas the individual effect of photoperiod was not significant $(\mathrm{p}=0.112)$. When considering all photoperiods taken together, mixture of forest topsoil and river sand resulted in a mean percentage germination of $97.22 \pm 1.02 \%$, which was higher than that recorded with top soil substrate $(85.55 \pm 4.0 \%)$. The lowest mean percentage germination (70 \pm $1.49 \%$ ) was recorded with river sand substrate (Table 2). When considering all substrates taken together, seeds exposed to a $12 \mathrm{~h} /$ day photoperiod germinated at $85.92 \pm 4.07 \%$, which was not significantly different from the $82.92 \pm 4.28 \%$ germination recorded with continuous darkness (Table 2).

\section{Desiccation tolerance}

Results of the desiccation tolerance test showed that fresh seeds of $C$. acuminata with initial moisture content of $59,91 \pm 3.9 \%$ performed a germination percentage of $81.5 \pm$ $11.5 \%$, and the conductivity of leachate was $49,6 \pm 0.5 \mu \mathrm{S}$. When seeds were dried, the germination percentage declined gradually with decreasing moisture content, while the electrical conductivity of leachate increased (Figure 1).

From 0 to 6 days of drying time, the moisture content slightly decreased from 59.91 $\pm 3.9 \%$ to $45.95 \pm 4.2 \%$ and the germination percentage was maintained between $81.5 \%$ and $72.5 \%$, meanwhile the electrical conductivity of leachate slightly increased from $49.6 \pm 0.5$ $\mu \mathrm{S}$ to $72.4 \pm 4.5 \mu \mathrm{S}$. At moisture content below $45.95 \pm 4.2 \%$, the germination percentage abruptly dropped to $41.66 \pm 1.5 \%$ at 8 days of drying time. At the same time, the electrical conductivity of leachate suddenly increased to $402 \pm 2.5 \mu \mathrm{S}$. The value of $45.95 \pm 4.2 \%$ was thus recorded to be critical moisture content. After 16 days of drying, the moisture content has decreased to $27.1 \pm 2.1 \%$ and the germination percentage was $0 \%$. The value of $27.1 \pm 2.1 \%$ was then recorded as the lethal moisture content. Seeds leachate conductivity exhibited a highly significant negative correlation with both germination percentage $(\mathrm{p}<0.01, \mathrm{r}=-0.926)$ and moisture content $(\mathrm{p}<$ $0.01, \mathrm{r}=-0.931)$. Moisture content and germination percentages were positively correlated $(\mathrm{p}<0.01, \mathrm{r}=0.945)($ Table 3$)$.

Table 1: Result of the analysis of variance showing the degree of freedom (DF) and the levels of significance ( $F$ and $p$-values) at which the substrate $(\mathrm{S})$, the photoperiod $(\mathrm{Ph})$ and combinations of substrate and photoperiod $(\mathrm{S} \times \mathrm{Ph})$ affected the percentage of $C$. acuminata seed germination.

\begin{tabular}{llll}
\hline Effects & DF & $\boldsymbol{F}$-value & $\boldsymbol{p}$-value \\
\hline $\mathrm{S}$ & 2 & 28.95 & 0.0001 \\
$\mathrm{Ph}$ & 1 & 12.03 & 0.112 \\
$\mathrm{~S} \times \mathrm{Ph}$ & 5 & 9.93 & 0.001 \\
\hline
\end{tabular}


Table 2: Germination percentages of Cola acuminata seeds at different photoperiods 45 days after sowing (45 DAS) on different substrates.

\begin{tabular}{lcccc}
\hline Photoperiod & \multicolumn{3}{c}{ Substrate } \\
\cline { 2 - 5 } & Topsoil & Sand & Topsoil + Sand & Photoperiod main effect \\
\hline 12 h.day $^{-1}$ & $86.66 \pm 1.92$ & $71.11 \pm 5.09$ & $98.88 \pm 1.92$ & $85.925 \pm 4.07^{\mathrm{ns}}$ \\
Darkness & $84.44 \pm 0.28$ & $68.88 \pm 8.38$ & $95.55 \pm 3.33$ & $82.923 \pm 4.28^{\mathrm{ns}}$ \\
Substrate main effect & $85.55 \pm 4.00^{\mathrm{b}}$ & $70.00 \pm 1.49^{\mathrm{c}}$ & $97.22 \pm 1.02^{\mathrm{a}}$ & \\
\hline
\end{tabular}

Notes: Within the last row, means \pm SE followed by different letters are significantly different according to Duncan multiple comparison test; ns: no significant difference between mean percentage germination at 12 h.day-1 photoperiod and mean germination percentage at continuous darkness.

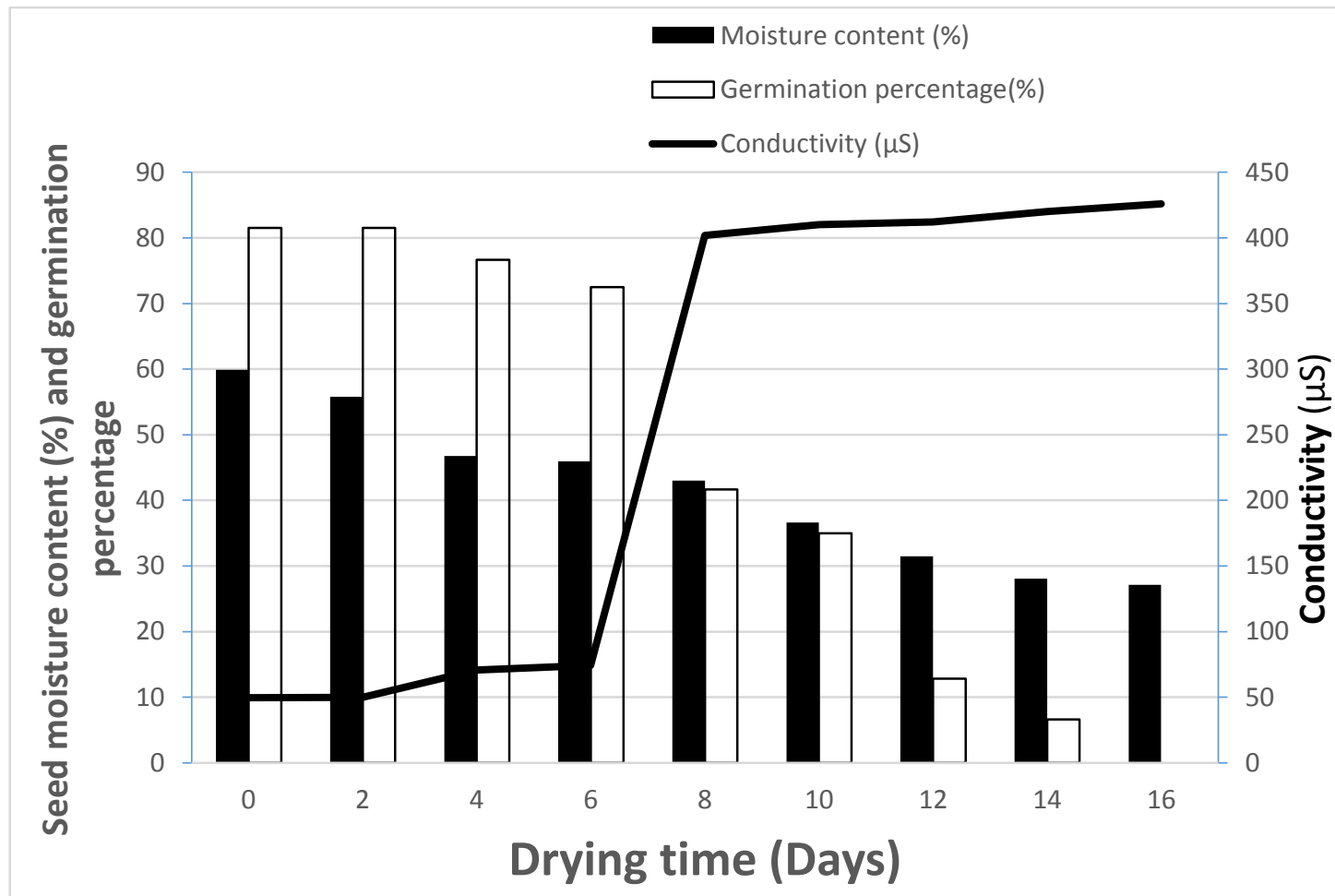

Figure 1: Variation in moisture content, germination percentage and leachate conductivity of Cola cauminata seeds during drying.

Table 3: Two tailed Pearson correlation coefficients between different Cola acuminata's seeds parameters.

\begin{tabular}{|c|c|c|c|}
\hline & Moisture content & conductivity & Germination percentage \\
\hline Moisture content & 1 & $-0.931 * *$ & $0.945 * *$ \\
\hline Conductivity & & 1 & $-0.926 * *$ \\
\hline Germination percentage & & & 1 \\
\hline
\end{tabular}




\section{DISCUSSION}

Substrates had a significant influence on germination percentage of $C$. acuminata seeds, with mixture of topsoil and river sand resulting in highest germination percentage, followed by topsoil. Similar results have been reported with the related species $C$. anomala (Kanmegne et al., 2015) and other tropical seeds among which Xylopia aethiopica (Kanmegne et al., 2017), although ISTA (2004) has recommended sand as substrate for seed germination in some species. To promote seed germination, a substrate needs to have appropriate aeration and moisture (Khurana and Singh, 2001; Sounou et al., 2009). As seeds were partially buried in the present experiment, there was no problem of seed aeration. The differences among substrates for their germination percentage which is reported in this study may be attributed in differences in moisture retention. Indeed, both topsoil and mixture of topsoil and river sand substrates contain organic matter which is responsible of high water retention capacity (Rawls et al., 2003). The very low amount of organic matter in river sand, which resulted in lower water retention, may have lowered the germination percentage.

In relation to the desiccation sensitivity test, the moisture content recorded with fresh C. acuminata seeds was very high $(59.91 \%)$. Such high moisture content in fully mature seeds is characteristic of recalcitrant seeds which do not undergo maturation drying and whose water content range from 30 to $70 \%$ even after shedding from mother plant (Martins et al., 2003; MSBP, 2005). Seeds' moisture content significantly affected the germination ability. Fresh seeds with high initial moisture content had the maximum germination percentage $(81.5 \pm 11.5 \%)$. In response to drying, the mean germination percentage decreased with decreasing moisture content, and below the moisture content of $27.1 \pm 2.1 \%$ there was no seed germination. The depletion in germination ability as a consequence of loss of moisture indicates that $C$. acuminata seeds are desiccation-sensitive and can thus be classified as recalcitrant seeds. In such seeds, a slight depletion of germination is observed when seeds begin to dry (Barbedo and Bilia, 1998). The viability of seeds is then drastically reduced at a certain level of moisture which is considered as critical moisture content. The value of $45.95 \pm 3.3 \%$ reported in the present study as the critical moisture content is lower than the value of $50.28 \%$ which was obtained with the related species $C$. anomala. Moreover the value of $27.1 \pm 2.1 \%$ recorded in this study as lethal moisture content is lower the $32.24 \%$ which was recorded with $C$. anomala seeds (Kanmegne et al., 2015). This is an indication that within recalcitrant seeds, the values of critical and lethal moisture contents may vary from a species to another.

Electrical conductivity of seed leachate exhibited a strong negative correlation with both moisture content $(\mathrm{p}<0.01, \mathrm{r}=-0.931)$ and germination percentage $(\mathrm{p}<0.01, \mathrm{r}=-0.926)$. This result shows that electrical conductivity of seeds leachate can be retained as a good indicator of seeds viability in C. acuminata seeds, as previously reported with seeds of other forest species (Samarah, 2006; Panobianco et al, 2007; Asomaning et al., 2011; Ramos et al., 2012; Kanmegne et al., 2015).

From previous studies (Sacandé et al., 2001; Khan et al., 2003) it has been suggested that electrolytes leakage from tissues can be used to indicate the effectiveness of cellular membranes as barriers to solute diffusion. While relatively low levels of leakage indicate that cellular membranes are semi permeable, high levels of leakage indicate damage of membranes. There is evidence that if dehydration stress disrupts membrane integrity in desiccation-sensitive seeds, then the amount of solutes leaked will increase in response to dehydration, and these increases should be associated with loss of viability (Walters et al., 2001; Wesley-Smith et al., 2001). The results of the present study are consistent with these concepts and indicate that cellular membranes 
of desiccation-sensitive $C$. acuminata seeds may have been damaged as seeds were dried further as observed in the increases in the levels of solute leakage. Excessive dehydration of seeds beyond the critical moisture content may have severely disrupted the integrity of the cellular membrane of seed tissues, resulting in the uncontrollable rate of solutes leaked. In desiccation-sensitive seeds, cellular membranes are known to be unable to reform completely during imbibitions if previously damaged by dehydration below the critical moisture content (Kernode and Finch-Savage, 2002; Berjak et al., 2007).

\section{Conclusion}

From the present study it is concluded that the $C$. acuminata seeds are desiccationsensitive, with $45.95 \pm 3.3 \%$ and $27.1 \pm 2.1 \%$ as values of critical and lethal moisture contents respectively. Seeds dehydration caused cellular membranes disruption, electrolytes leakage and loss of seeds viability. For sexual propagation of $C$. acuminata, fresh mature seeds should be sown in substrate composed of mixture of forest top soil and river sand in a 1:1 (v:v) ratio. The recalcitrant behavior of $C$. acuminata seeds represents a significant constraint for conservation. This constraint needs to be addressed in further researches.

\section{COMPETING INTERESTS}

The authors declare that they have no competing interest.

\section{AUTHORS' CONTRIBUTIONS}

This work was carried out in collaboration between all the authors. GK designed the study, wrote the protocol, carried out the desiccation tolerance test and wrote the first draft of the manuscript. GFK collected the seeds in the field, carried out the germination trial in the nursery and participated to the desiccation tolerance test. TF provided critical inputs towards the research and corrected the manuscript. All authors read and approved the final manuscript.

\section{REFERENCES}

APG III (Angiosperm Phylogeny Group III) 2009. An update of the Angiosperm Phylogeny Group classification for the orders and families of flowering plants: APG III. Bot. J. Linn. Soc., 161(2): 105121. DOI: https://doi.org/10.1111/j.10958339.2009.00996.x

Asogwa EU, Agbongiarhuoyi AE, Mokwunye FC, Ndagi I, Adebiyi S, Ndubuaku TCN. 2012a. The challenges of kolanuts processing, trade and export from Nigeria and other sub-Saharan African countries. Int. J. Sci. Nature, 3(1): 06-11.

Asogwa EU, Otunde AH, Oluyole KA, Ndubuaku TCN, Uwagboe EO. 2012b. Kolanuts production, processing and marketing in the South Eastern states of Nigeria. Am-Euras. J. Agric. Environ. Sci., 12(4): 463-468.

Asomaning JM, Olympio NS, Sacande M. 2011. Desiccation sensitivity and germination of recalcitrant Garcinia kola Heckel seeds. Res. J. Seed Sci., 4(1): 1527. DOI: $10.3923 /$ rjss.2011.15.27

Atangana A, Khasa D, Chang S, Degrande A. 2014. Major Land Use Issues in the Tropics, and the History of Agroforestry. In Tropical Agroforestry, Springer Science + Business Media: Dordrecht; 23-33.

Barbedo CJ, Bilia DAC. 1998. Evolution of research on recalcitrant seeds. Sci. Agric., 55: 121-125.

Berjack P, Pammenter NW. 2001. Seeds recalcitrance - current perspectives. South Afr. J. Bot., 67: 79-89. DOI: 10.1016/S0254-6299(15)31111-X

Berjack P, Farrant JM, Pammenter NW. 2007. Seed desiccation tolerance mechanism. In Plant Desiccation Tolerance, Jenks MA, Wood AJ (eds). Blackwell Publishing: Ames; 151-192. 
Fotso, Omokolo ND, Mbouna D. 2002. Comparaison de l'aptitude à la régénération in vitro de deux colatiers : Cola anomala et Cola acuminata. Chahiers Agric., 11(5): 355-360.

Gebissa E. 2006. Kola is God's gift: Agricultural production, export initiatives and the kola industry in Asante and the Gold Coast c. 1820-1950 (review). Afr. Studies Rev., 49(3): 94-96. http://www.jstor.org/stable/20065285

ISTA (International Seed Testing Association). 2004. International Rules for Seed Testing. Rules 2004. International Seed Testing Association: Zurich.

Kanmegne G, Anouma'a M, Fotso, Mbouobda HD, Mbibong DA, Omokolo DN. 2015. Germination of Cola anomala (K. Schum) Schott and Endl. seeds: effects of provenance, substrate and dehydration. Int. J. Biol. Chem. Sci., 9(3):1171-1180. DOI: http://dx.doi.org/10.4314/ijbcs.v9i3.3

Kanmegne G, Mbibong DA, Fotso, Omokolo DN. 2017. Effects of substrates, different pretreatment protocols and dehydration on the induction of seeds germination of Xylopia aethiopica (Dunal) A. Rich. Int. J. Biol. Chem. Sci., 11(2): 597-608. DOI: https://dx.doi.org/10.4314/ijbcs.v11i2.6

Kernode AR, Finch-Savage WE. 2002. Desiccation sensitivity in orthodox and recalcitrant seeds in relation to development. In Desiccation and Survival in Plants: Drying without Dying, Black M, Pritchard WH (eds). CABI Publishing: Wallingford; 149-184.

Khan MM, Alam MA, Abbas M, Iqbal MJ. 2003. Studies on desiccation tolerance in four Citrus species. Pak. J. Agric. Sci., 40: $55-62$.

Khurana E, Singh JS. 2001. Ecology of seeds and seedling growth for conservation and restoration of tropical dry forest: a review. Environ. Conserv., 28: 39-52. DOI: $10.1017 / \mathrm{S} 0376892901000042$
Kokutse AD, Adjonou K, Guelly AK, Kokou K. 2014. Bamboo resources in Togo. Int. J. Biol. Chem. Sci., 8(2): 481-493. DOI: http://dx.doi.org/10.4314/ijbcs.v8i2.8

Leakey RRB, Tchoundjeu Z. 2001. Diversification of tree crops: domestication of companion crops for poverty reduction and environmental services. Exp. Agric., 37(3): 279-296. DOI: $10.1017 /$ S0014479701003015

Lim TK. 2012. Edible Medicinal and Nonmedicinal Plants (Vol. 3: Fruits). Springer: Dordrecht-New York.

Martins CC, Bovi MLA, Nakagawa J. 2003. Desiccation effects on germination and vigor of King palm seeds. Hort. Braz., 21(1): 88-92. DOI: $10.1590 /$ S010205362003000100019

MSBP (Millenium Seed Bank Project). 2005. Post Harvest Handling Technical Information Sheet 4. Royal Botanic Garden: Kiew.

Panobianco M, Vieira RD, Perecin D. 2007. Electrical conductivity as an indicator of pea seed aging stored at different temperatures. Sci. Agric., 64(2): 119-124. DOI: 10.1590/S010390162007000200003

Ramos KMO, Matos JM, Martins RC, Martins IS. 2012. Electrical conductivity testing as applied to the assessment of freshly collected Kielmeyera coriaceae Mart. seeds. Int. Scholarly Res. Network (ISRN) Agronomy, 5 pages. DOI: https://dx.doi.org/10.5402/2012/378139

Rawls WJ, Pachepsky YA, Ritchie JC, Sobecki TM, Bloodworth H. 2003. Effect of soil organic carbon on soil water retention. Geoderma, 116(1-2): 61-76. DOI; https://doi.org/10.1016/S00167061(03)00094-6

Sacandé M, Golovina EA, van Aelst AC, Hoekstra FA. 2001. Variability loss of neem (Azadirachta indica) seeds associated with membrane phase behavior. J. Exp. Bot., 52: 919-931. DOI: 10.1093/jexbot/52.358.919 
Samarah NH. 2006. Effect of air-drying immature seeds in harvested pods on seed quality of common vetch (Vicia sativa L.). New Zealand J. Agric. Res., 49(3): 331-339.

DOI: https://doi.org/10.1080/00288233.2006.9 513723

Sinclair FL, Joshi L. 2001. Taking local knowledge about trees seriously. In Forestry, Forest Users and Research: New Ways of Learning, Lawrence A (ed). ETFRN: Wageningen; 45-61.

Sounou M, Glele Kakai R, Avakoudjo J, Assogbadjo AE, Sinsin B. 2009. Test de germination et de croissance de Artemisia аппиа $\mathrm{L}$. anamed sur différents substrats au Bénin. Int. J. Biol. Chem. Sci., 3(2):
337-346.

DOI: http://dx.doi.org/10.4314/ijbcs.v3i2.4450 5

Walters C, Pammenter NW, Berjak P, Crane J. 2001. Desiccation damage: "accelerated aging" and metabolism in desiccation tolerant and sensitive seeds. Seed Sci. Res., 11: 135-148. DOI: https://doi.org/10.1079/SSR200168

Wesley-Smith J, Pammenter NW, Berjak P, Walters C. 2001. The effects of two drying rates on the desiccation tolerance of embryonic axes of recalcitrant Jackfruits (Artocarpus heterophyllus Lam.) seeds. Ann. Bot., 88: 653-664. DOI: 10.1006/anbo.2001.1519 